\title{
Bronchial fibroblasts modulate CD4+Tcells phenotype towards Th17 in asthma
}

\author{
Lionel Loubaki', Eric Jacques, Sophie Plante, Jamila Chakir \\ From AllerGen NCE Inc.'s Fifth Annual Research Conference: Innovation from Cell to Society \\ Québec City, QC, Canada. 7-9 February 2010
}

\section{Objective/purpose}

In asthma, $\mathrm{CD} 4+\mathrm{T}$ cells are selectively recruited into the bronchial mucosa. CD4+ T cells consist of different subsets that express lineage specific transcription factors and play different roles either in initiating and supporting the development of immune response, but also in orchestrating and regulating them. The aim of our study was to evaluate the effect of $\mathrm{T}$ cells-bronchial fibroblasts interaction on $\mathrm{CD} 4+\mathrm{T}$ cell phenotype.

\section{Methods}

Human bronchial fibroblasts were isolated from mild steroid naïve asthmatics and non-atopic healthy controls. CD4+T cells were purified from the peripheral blood of healthy and asthmatic subjects. Co-culture of confluent healthy (HF) or asthmatic bronchial fibroblasts (AF) with $\mathrm{T}$ cells were performed. CD4 $+\mathrm{T}$ cell total RNA was purified and GATA-3, Foxp3 and RORc expression was detected by quantitative PCR. Th17 (IL17, IL-22) lineage specific cytokines profile was also evaluated.

\section{Findings}

Co-culture of $\mathrm{T}$ cells with bronchial fibroblasts significantly stimulated RORc in asthmatic $\mathrm{T}$ cells only, whereas Foxp3 and GATA-3 were not affected in both asthmatic and healthy T cells. IL-6 and IL-23 expression either by AF and HF were also significantly increased by the co-culture when TGF- $\beta$ expression was not affected. In CD4+ T cells, IL-17 and IL-22, Th17 lineage specific cytokines were significantly increased by the co-culture with AF.

Centre Recherche, Institut Universitaire de Cardiologie et de Pneumologie de Québec, Université Laval, Québec, Québec, G1V 0A6, Canada

\section{Deliverables and relevance}

Interaction between bronchial fibroblasts and $\mathrm{T}$ cells seems to specifically promote a Th17 cell profile in asthma. These results suggest that cellular interactions, particularly between $\mathrm{T}$ cells and fibroblasts, may play a pivotal role in the regulation of the inflammatory response in asthma.

Published: 26 November 2010

doi:10.1186/1710-1492-6-S3-P22

Cite this article as: Loubaki et al:: Bronchial fibroblasts modulate CD4

+Tcells phenotype towards Th17 in asthma. Allergy, Asthma \& Clinical Immunology 2010 6(Suppl 3):P22.
Submit your next manuscript to BioMed Central and take full advantage of:

- Convenient online submission

- Thorough peer review

- No space constraints or color figure charges

- Immediate publication on acceptance

- Inclusion in PubMed, CAS, Scopus and Google Scholar

- Research which is freely available for redistribution 